\title{
Guinea pig膵に見られた異形小型「ラ」氏島
}

\author{
竹内 節彌 \\ 日本医科大学名誉教授
}

\author{
Atypical small L-islets in guinea pig's pancreas \\ Setsuya Takeuchi \\ Prof. Emer., Nippon Medical School
}

Gomori 染色を施した guinea pig膵標本に扎いて は，ラット・イヌ・ウサギの場合よりも，「ラ」氏島の 細胞が、各細胞種ごとに，より一層鮮明に染め分けられ ている.「ラ」氏島構成細胞種の demonstrationには guinea pigの膵が利用されることが多いのはこのこと に基づいているのであるが，今回筆者は，膵「ラ」氏 島およびその構成細胞がはなはだ奇異な存在様態を示 す guinea pig 膵標本に遭遇したので, その写真の数枚 を例示し，諸家の参考に供したい。

日本医科大学実験動物管理室にて 1 力月以上飼育さ れていた Hartley 系, 雄性 guinea pig を放血致死せし め, 膵片を摘出, Zenker-formol (neutral) 液に投入, 固定し，しかる後 Gomori 染色を施した。また，一部 は Hellman-Hellerström 法による鍍銀標本の作製に 供した。

なお，屠殺前のこの動物は空腹時血糖值に異常を示 さず，尿糖は陰性であった。

Photo 1,2 にはこの動物から得られた典型的な「ラ」 氏島像を示す.Photo 1 の「ラ」氏島構成各細胞内の alpha-granule, beta-granule それぞれの染色性に異常

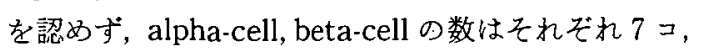
63 コであって, 既報の guinea pig 膵「ラ」氏島標本に 执ける平均值 $11 \pm 5$ コ, $75 \pm 27$ コに比べて特に有意の 差を認めない。をた近接部位に対する錙銀標本におい ては, 島内に複数の突起を有する delta-cell 鍍銀像を 多数認めることができる(Photo 2)。またその複数の 突起の内の少なく々も一本は，その先を小血管壁にま で伸ばしている状態を明瞭に観察することができる。

\section{1. 小「ラ」氏島の発現}

Photo 1,2 が得られたのと同一のプレパラート上に おいて, 多数の beta-granule を有する細胞 (beta-like cell）が acinal tissue の中に散在しているのが発見さ れた (Photo 3 参照).これら beta-like cell は1コの 又の場合もあり，2ないし 5 コほどかたまって存在す る場合もあった。 また， 3 こ以上集まっている場合に は, alpha-granule と覚しい顆粒を有する細胞 (alphalike cell）が隣接しているのがしばしば観察された。

Photo 4 は Photo 3 の映像に相当する部位の鍍銀 標本より得られたるのであるが，被鍍銀細胞（deltalike cell）もまた acinal tissue 中に散在しているのが 発見された。

acinal tissue 中に位置する上記二種の細胞はそれぞ れ単独で存在する場合はもとより数コ集まって存在す る場合でも，その周囲の capsuleの存在は確認されな かった。

Fig. 1 は, 1 ブレパラート上に存在する beta-cell の 数に基づいてその分布を示したるのである（図中 beta-cell と記したものは beta-granule を含有する細 胞，つまり beta-like cell の意味である).

横軸は一つの集まりの中の beta-cell の数を対数ス ケールで表し，綎軸はそれぞれの集まりを「ラ」氏島 1 コと見なした場合の数を実数で表した。

「ラ」氏島数は構成 beta-cell 数が増えるにつれては ぼ直線的に減少するが, 構成細胞数が 60 以上 120 以下 の範囲で, 再び増加する傾向を示す。

Photo 1 に例示したような guinea pig 萃「ラ」氏島 に打ける平均 beta-cell 数は $77 \pm 20$ である.すなわち, このグラフに示された細胞数 60 240を頂点とする分 布曲線は, 正常 guinea pigのそれと一致する。 


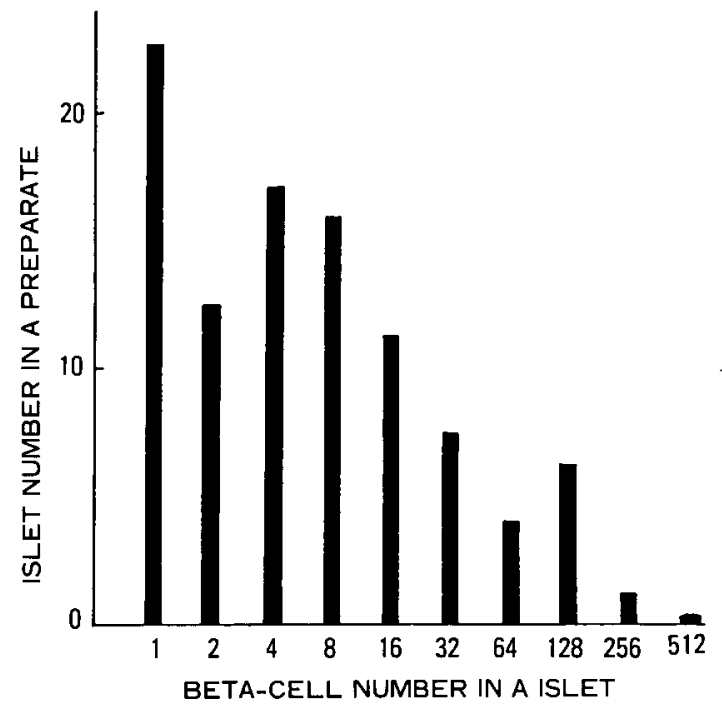

Fig. 1 Relation between the cell-number and the $\mathrm{L}$-islet-number in guinea pig's pancreas

検討：構成 beta-cell 数が比皎的少ない集まりの場 合, その数は構成細胞数の増加につれて指数関数的に 减少する。このことは，1ないし数コからなる betacell の集まりというある意味では極めて異常な映像 が，必ずしも標本作製時や写真撮影時の artifact に由 来するものではないことを明瞭に示している。すすなわ ち，もし acinal tissue 中に散在しているように見兄る これらの beta-granule 含有細胞が，元来は「ラ」氏島 内に存在しており，標本製作時の切面がたまたま「ラ」 氏島の端をかすめたためにこのような像を呈したもの であるとすれば, 構成 beta-like cell 数が少なくなれば なる汪ど集まりの数むまた少なくなるはずであるから である。また、これらに周囲に明膫な capsule の存在を 認めなかったといら事実もこれらが「ラ」氏島内に存 在しているのではないという見解を支持するだろう。

構成細胞数が増加するに連孔て「ラ」氏島数が指数関 数的に減少するという事実は，このプレパラートに見 られる所見が「ラ」氏島自身の成長過程の一断面像で あることを明瞭に物語っている。したがって，上記の ような特殊な beta-granule 含有細胞や被鍍銀細胞の 在り方を説明する唯一の想定は, 動物居殺時に比較的 近い過去のある時点において beta-cell, delta-cell の 新生過程が一定の時期を画して発現したという仮説で あろう、いうまでもなく、この beta-cell, delta-cell の 新生過程がこの動物の生来的な特質に基づくるのと考 えることは絶対できない，なぜなら，この標本上に発
見される「ラ」氏島数が構成細胞数 $60 \sim 120$ の範囲に 扣いて二項分布に相似の分布型を示したということ が,この動物が生をれてからある一定の時期をで,「ラ」 氏島の発育が正常であったことを示すものであるから である。しかも，この分布曲線は先述の指数分布曲線 とは明らかに不連続であるから，この動物が屠殺時に 近接した時点に抗いて，ある種の pathologic process を体験し，その後に起こった修復過程の一部を，われ われが目にしているのだと考方るのが最す自然である ことになる. 前述のごとく, 鍍銀標本に抢いても多数 の被鍍銀細胞が acinal tissue 内に散在していること が見出さ机ているので, delta-cell の新生過程もまたこ の時に起こったものと考充なくてはならない。すなわ ち, この過程は複合的であって，「ラ」氏島そのものの 新生過程と見なすことがでさるだろう。

最近, 金沢康徳氏らは Hartley 系 guinea pig の insulin receptor の数が他の動物種の 3 ないし 4 倍多 いことを見出した (personal communication)。また， Humbel ら リンに対してラットは低い感受性しか示さなかったと 報告している。これらの事実は, Humbel らの使用した guinea pig が自己のインシュリン，あるいは「ラ」氏 島組織に対するある種の抗体を持っていた可能性があ ることを示唆している。むしこの金沢氏や Humbel ら の観察した guinea pig の特殊な抗体産生能と,われわ れの guinea pig 膵標本に和ける顕著な「ラ」氏島新生 像とを関連させて考劣ることが許されるならば, また， そこに想定される一定の pathological process $と$, 実 験動物としてのモルモットの飼育管理の不完全さとを 関連させることが許されるならば，今回のわれわれの 観察はさらに多くの今後の展望を期待しうるものとな るだろう。それにはまず，われわれの飼育している実 験動物中の何\%にこのような異常所見が見出だされる のかを決定することが急務であるに違いない。

\section{2. 腺房組織中の beta-like cell, delta-like cell}

Photo 5,6に見られるよらな, acinal tissue 中に散 在する beta-granule 含有細胞 (beta-like cell) 拉よび 被錣銀細胞（delta-like cell）の在り方にはそれぞれに 個性的な特徵が認められた。

1) acinal tissue 中の beta-like cell の内側に，それもその中央部付近に位置していた (Photo 5).

2) acinal tissue 中の delta-like cell の大部分は 


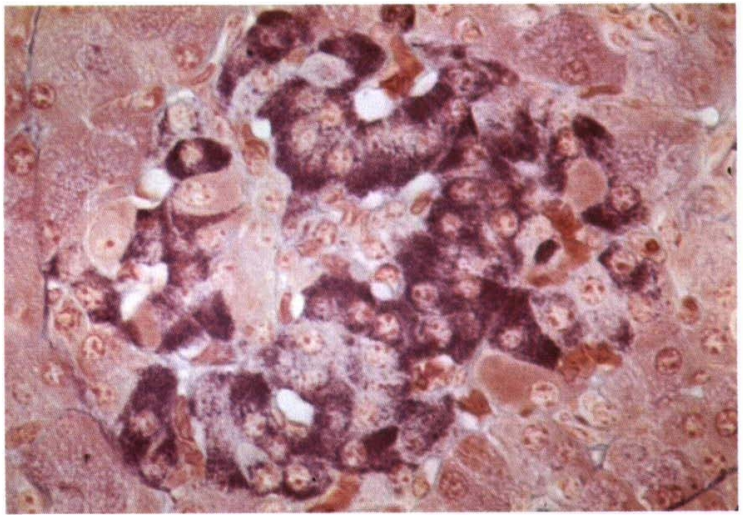

Photo 1 Gomori-staining $(\times 400)$

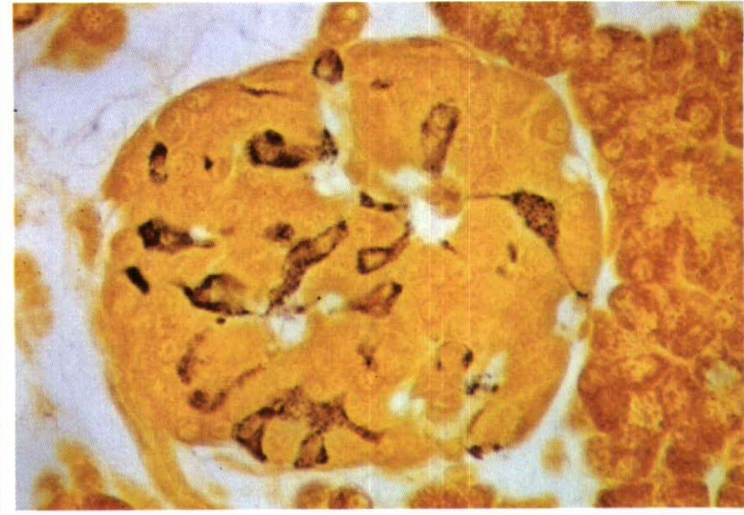

Photo 2 Hellman-Hellerstrom's plating $(\times 400)$

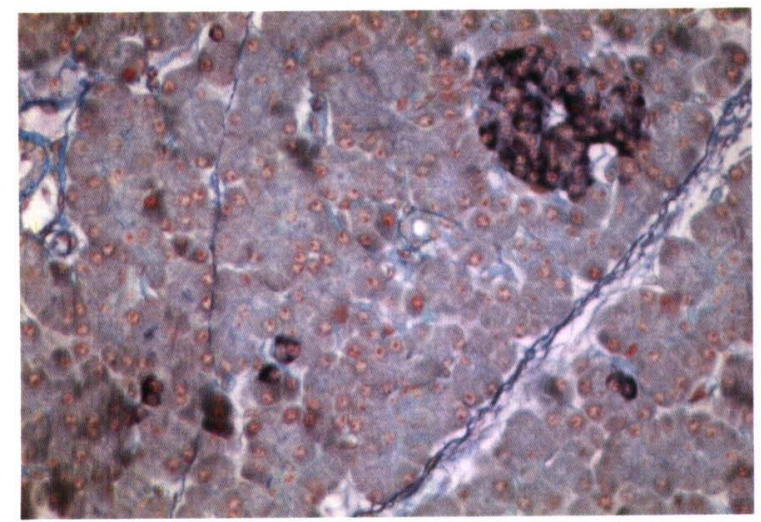

Photo 3 Gomori-staining $(\times 200)$

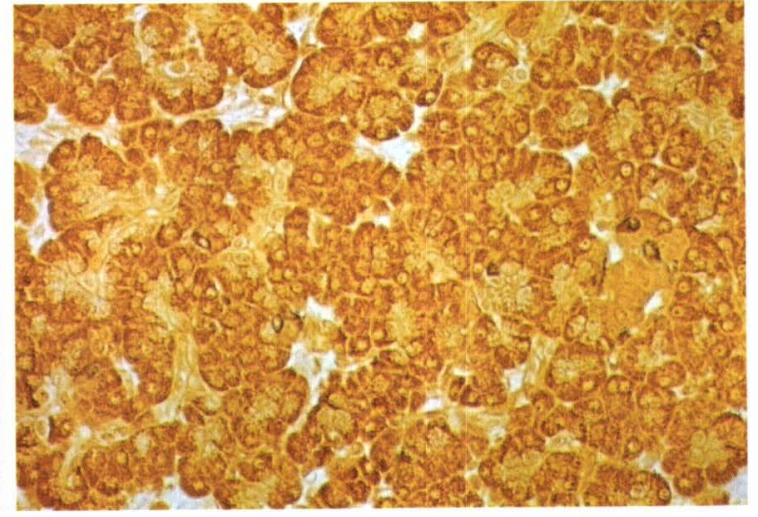

Photo 4 Hellman-Hellerstrom's plating $(\times 200)$

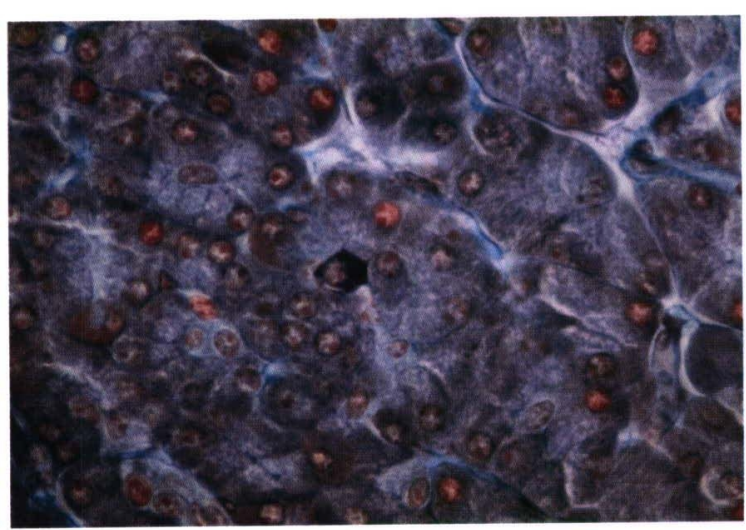

Photo 5 Gomori-staining $(\times 400)$

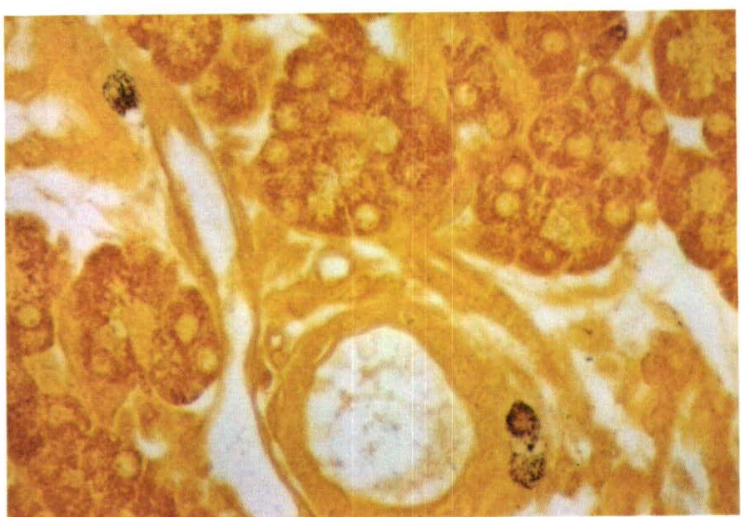

Photo 6 Hellman-Hellerstrom's plating $(\times 400)$ 
acinus の内側部位に発見されるのだが，その一部は acinusの外側の結合組織の間に位置するるのがあっ た.Photo 6 に見られる delta-like cell は比較的太い 導管・血管の周辺に位置している。交た，このよらな acinusの外側に位置する被鍍銀細胞の中には小血管 壁に1本の突起を伸ばしているものがあった。

検討：この動物が過去に一定の疾患を経過したとい う前提に立つと, acinal tissue 中に散在する beta-like cell あるいは delta-like cell の在り方は，ある条件下 に扮ける「ラ」氏島の発生機序を示唆していることに なる。すなわち beta-like cell が常に acinus の中央部 付近，つまり腺空比接して発見されるといら事実は beta-cell centro-acinal cell から発生するものであ ると把握する従来の定説に合致している。しかし，一 方の delta-like cell は acunus の外側にも位置するこ とがあるのであるからこれもまた acinus の中の細胞 から発生してきたものであると考点ることはできな い、な，この種の細胞はしばしば小血管壁と連絡す る突起を有するので，その由来はむしろ interacinal tissue 中のいずれかの細胞に求められるべさだろう。 「ラ」氏島外に発生した delta-like cell は「ラ」氏島発 生時に必ず発見される強度の毛細管増殖に伴って acinusの中央部に進入するるのと考光られる。これは delta-cell が interacinal ganglion 内の交感神経細胞 とその起源を同じくするといら従来の私見 なる事実であるに違いない。

しかし、これまで beta-like cell, delta-like cell とわ れわれが呼んできた「ラ」氏島外の細胞がそれぞれ beta-cell, delta-cell であるという確証はまだ得られて

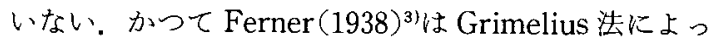
て鍍銀された細胞が acinus の外側に発見されること があること，ならびに小血管壁に連絡肢を伸ばしてい ることを報告した，Grimelius 法による被鍍銀細胞は alpha-cell であると信じた彼らは alpha-cell の由来を acinus 外の細胞に求める考光を明らかにした。しかし 一方, Möllendorff (1939)4)はウサギ胎仔の膵におい て, Hellman-Hellerström 法によって鍍銀される細胞 が acinusの外側に位置しているのを見出した。

元来鍍銀法には数種類の方法が報告されているので あるが，それぞれの鉸銀条件には互いにわずかな相違 があり，そのわずかな差によって鍍銀される細胞種が 異なるとされてきたことは紛れもない。しかしわずか な鍍銀条件の相違のみに基づいて逆に島細胞種を云々 するのは多くの危険を伴う可能性があるだろう。また 同時に,「ラ」氏島外に位置する細胞の染色性が島内の 該当細胞のそれと全く等しいとする保障もない：これ らの細胞の種を決定するには，醭素抗体法による染色 法や electron-microscopy に上る検索などが十分利用 される必要がある。そしてこれらの方法を駆使して， さらに多くの観察例を重祆ることが必要であると思わ れる。

\section{文 献}

1) Humbel, R.E., Bosshard, H.R. and Zahn, H.: Chemistry of insulin. "Handbook of Physiology Sec. 7 Endocrinology" (Greep, R.O. and Astwood, E.B. eds.), Vol. 1, p. $111 \sim 132$, American Physiological Society, Washing ton, D.C., 1972.

2）竹内節襄：脺「ラ」氏島の自律神経支配. 第24回日本楉尿病 学会関東甲信越地方会, 東京, 1987-01, 糖氺病, 31，323, 1988.

3) Ferner, H.: Uber die Entwicklung der Langerhansschen Inseln nach den Geburt und die Bedeutung der versilberbaren Zellen in Pankreas des Menschen. Ztschr. f. mikr. anat. Forsch., 44, 451 488, 1938.

4) von Möllendorff, W.: Die Langerhansschen Inseln des Pankreas. "Handbuch der Mikroskopischen Anatomie des Menschen", p. 197 275, Verlag von Julius Springer, Berlin, 1939. 